\title{
Financial Performance and Liquidity Trends of Banks in an Emerging Economy: Evidence from Ghana
}

\author{
Michael Ayikwei Quarshie ${ }^{1 \times}$ \\ Reginald Djimatey ${ }^{2}$ (D)
}

\author{
1.2Department of Entrepreneurship and Business Sciences, University of Energy and Natural Resources, Sunyani, \\ Bono Region, Ghana.

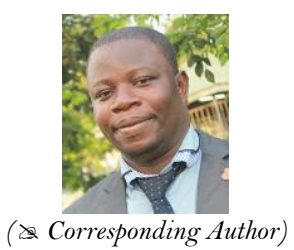

\begin{abstract}
The purpose of this study was to analyse financial performance and liquidity trends of banks in the financial sector of Ghana. A review of literature on performance and liquidity was conducted owing to the challenges the banks are confronted with. The study analysed 180 annual reports of the banks during the periods 2006-2015. The analysis revealed that banks were relatively liquid in most of the study periods except in the years 2013 and 2014, where the average liquidity was 1.54 and 1.41 respectively. The highest liquidity of 2.183 was recorded in 2011 , which indicates that Ghe 2.183 of current assets available covers Ghe 1 of current liabilities. The financial performance of the banks was fairly intermittent during the study periods. The lowest financial performance of the banks was recorded in the year 2006. An average financial performance of $6.74 \%$ and $0.83 \%$ for return on equity (ROE) and return asset on (ROA) respectively was recorded in 2006. While the year 2014 recorded the highest financial performance of $24.23 \%$ for return on equity and $4.57 \%$ for return on asset owing to favourable economic conditions in the country in that year. The study recommends that bank managers should adopt effective liquidity management to ensure the banks are operating profitably. Since it has been empirically proven that high liquidity rates will provide for better financial results.
\end{abstract}

Keywords: Liquidity, Banks, Financial performance, Return on equity, Return on assets, Current ratio, Acid-test ratio. JEL Classification: M41.

Citation | Michael Ayikwei Quarshie; Reginald Djimatey (2020) Financial Performance and Liquidity Trends of Banks in an Emerging Economy: Evidence from Ghana. Asian Journal of Social Sciences and Management Studies, 7(2): 135-142.

\section{History:}

Received: 17 March 2020

Revised: 20 April 2020

Accepted: 22 May 2020

Published: 4 June 2020

Licensed: This work is licensed under a Creative Commons

Attribution 3.0 License (co)

Publisher: Asian Online Journal Publishing Group
Acknowledgement: Both authors contributed to the conception and design of the study.

Funding: This study received no specific financial support

Competing Interests: The authors declare that they have no conflict of interests.

Transparency: The authors confirm that the manuscript is an honest, accurate, and transparent account of the study was reported; that no vital features of the study have been omitted; and that any discrepancies from the study as planned have been explained.

Ethical: This study follows all ethical practices during writing.

\section{Contents}

1. Introduction

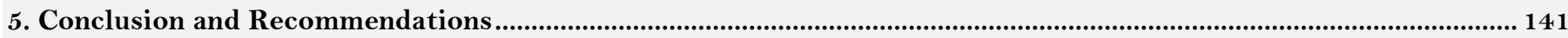

References.... 


\section{Contribution of this paper to the literature}

The outcome of this study contributes to the existing literature as it provides useful information on managing liquidity risk and adopting appropriate liquidity management practices that offer a competitive advantage to banks and other financial institutions.

\section{Introduction}

Liquidity is viewed as the ability of a firm to readily meet all its short-term obligations as and when they fall due. Most often liquidity is used to refer to situations were liquid assets thus cash and any other assets that can easily be converted into cash at no extra cost. According to the Board of Governors of the Federal Reserve System (2014), liquidity is a measure of the ability and facility with which a company's assets can be converted into cash to settle maturing financial obligations. A higher ratio means greater liquid asset coverage to short-term maturing obligations, which ensures the company will be able to meet all its maturing obligations and finance its ongoing operations (Certified Management Accountant (CMA) Australia, 2013). Nevertheless, unproductive use of capital could be denoted by a significantly higher ratio and a lower ratio could also mean insolvency. However, a 2:1 ratio is considered appropriate according to Certified Management Accountant (CMA) Australia (2013). The value of liquidity cannot be overemphasized for any business organization. Many businesses fail not because of competitiveness but because of lack of cash (Rob, 2010). The benefit is worthless, according to Rob, unless it can be converted to cash by debtors' receipts. An otherwise profitable company can still fail if it has a cash flow problem. Banks are particularly vulnerable when it comes to liquidity risk due to their position of financial intermediation in any economy. Amer (2007) commented that financial intermediaries whose assets are typically less liquid than their liabilities and depend on their continued viability in paying the liabilities are exceptionally vulnerable when it comes to liquidity risk.

Gomez (2008) intimated that clients' assurance will be significantly dented in the banking sector if banks cannot meet customers ' withdrawal needs. Gomez further stressed that a bank's continued existence is based on public trust, and the bank can only build that trust if it can convert its assets into cash to meet depositors ' requests for withdrawal. To remain viable, financial institutions should have sufficient liquid assets in place to meet their maturing obligations (Board of Governors of the Federal Reserve System, 2014). For this reason, as part of its regulatory role, the Bank of Ghana $(\mathrm{BoG})$ allows banks doing business in Ghana to have an Assets and Liabilities Management Committee (ALCO), which meets at least once a month to review the financial statement of the bank among other functions by looking at sources and applying funds against costs and yields. In addition to ALCO, banks operating in Ghana are required to submit a weekly liquidity report showing compliance or non-compliance with the mandatory primary reserve ratio among other statistics. Current ratio, fast (acid test) ratio and cash ratio are the most common liquidity measures. Nevertheless, other liquidity mechanisms, such as the loan deposit ratio (LDR), liquid assets to total deposits, and so on, exist in the banking business apart from the above. It is reasonable to expect banks to keep some cash to alleviate their short-term obligations, particularly depositors' withdrawal needs, and also to take advantage of investment opportunities to make some profit for their shareholders (Tan, 2005). Alongside the required 10\% primary reserve ratio (PRR) and the prudential $3 \%$ cash reserve ratio (CRR), which the Bank of Ghana allows banks doing business in Ghana to maintain.

Relying too heavily on profitability may mean ignoring the risk associated with achieving higher returns, thereby endangering customer deposits. Nonetheless, to return interest to their owners, banks would need to make a profit. To overcome this issue, section 31 of the Banking Act, 2004, Act 673, allowed the BoG to place liquidity conditions on banks to declare that banks hold such funds on their financial statements as protection for customer deposits. Banks can, however, choose to keep these assets over the regulatory requirements set by the BoG. Failure to comply with the provisions of section 31 could lead to certain punitive measures, as provided for in section 33 of Act 673 . The relationship between financial performance and liquidity of banks has been a subject of disagreement among researchers and players in the industry. Some have pointed to the relationship being more analytical than perceptional. A study by Lartey, Antwi, and Boadi (2013) found a clear, positive correlation between bank profitability and liquidity in Ghana. Banks in Ghana, especially in the last few years, are embroiled in a serious war over deposit mobilization to raise their customer deposits as if higher customer deposits would necessarily ensure better financial performance. Banks consistently run deposit promotions, hiring large sales staff and expanding vast branch network across the country's length and breadth. Such machinations cost significant sums of money and other resources which adversely affect the banks' liquidity and financial positions, hence the need to analyse financial and liquidity trends of banks in the financial sector of Ghana. The rest of the study is presented as follows: Section 2 focuses on the literature review. Section 3 examines the methodology. Section 4 presents the results and discussion. Finally, Section 5 captures the conclusion and recommendations drawn from the study.

\section{Literature Review}

\subsection{Self-Liquidating Paper Theory}

Self-liquidating paper theory was widely accepted as a means of keeping banks liquid. According to Leonard (2011), the bank's short-term loans to fund saleable goods from the manufacturer to the customer are the most liquid credits the bank can advance. These were known as self-liquidating loans, as the funded goods were soon sold and the debt paid off. Such self-liquidating short-term loans have been advanced to meet the borrowers' working capital requirements. Shekhar and Shekhar (2005) claim that self-liquidating commercial papers or shortterm loans are intended to provide existing, self-liquidating working capital. A bill of exchange, usually an example of a self-liquidating document from a real trade transaction, which is a secured loan from physical goods that can be repaid from the price of their sales (Gomez, 2008). Often called commercial loan theory, the theory allows banks to refrain from long-term lending. Gomez (2008) criticized the commercial loan hypothesis for having negative effects on business activities and the borrowers ' purchasing power if all bank loans were real bills or all banks attempting to cut their loans; also in depression periods, goods do not move readily into the normal channels of trade and may occasion some losses to sellers. Therefore, the traders are not able to meet the bills on maturity. 


\subsection{Shiftability Theory}

Moulton (1918) propagated this theory to replace the self-liquidating paper theory, though loans remained an important source of liquidity for banks. The theory holds that bank liquidity is retained if it has assets which, if appropriate, can be transferred to other banks before maturity. An entity can preserve liquidity by maintaining assets that can be quickly moved, transferred, or sold for cash with minimum transaction costs or value loss (Bhattacharya, 2008). Gomez (2008) asserted that if the assets held could be transferred or sold to the central bank which is the lender of last resort, the optimum shiftability is achieved. The bank will hold highly marketable securities which are readily transferable for liquidity to other banks and the central bank. The theory argues that the bank should obtain assets that are shiftable, marketable and transferable to ensure that when the need arises, they can create some liquidity for the bank. The major criticism of this theory is that during times of depression cost of shifting assets may be high because securities would not be attractive to buyers.

\subsection{Overview of Ghanaian Banking Industry}

The banking sector in Ghana, since the turn of the 21 st century, has been the most active in the economy, showing steady growth in both assets and profitability. The successes of the banks largely resulted from the passage of the Bank of Ghana Act 2002, Act 612 and the Banking Act 2004, Act 673 combined with the liberalization of the banking sector. These initiatives saw the issuance of universal banking business licenses and the relaxation of the conditions for entry into the banking business. Such innovations have brought many Nigerian banks into the industry with advanced technology, unparalleled customer support and product innovation; forcing existing banks to strengthen their systems and processes in equal measure (Bawumia, Owusu-Danso, \& McIntyre, 2008). Some analysts do not share this view and argue that growth in the banking sector is only in tandem with the growth in the Ghanaian economy, now a lower-middle-income economy. The financial services sector appears to be undergoing some rapid global transformation. These changes have arisen owing to economic deregulation, government policies, globalization and information communication technology. This transition has led to intense competition across the globe within the financial services industry, requiring financial institutions to constantly offer a range of financial products to thrive and remain competitive. Initially, the banking sector in Ghana was listed as private, merchant and development banks. Whilst merchant banks were limited to corporate clients, the development and commercial banks served customers across the entire spectrum (Antwi-Asare \& Addison, 2000).

It was against this backdrop that the need to create a level playing field for all banks operating in Ghana was introduced, hence the concept of uniform banking business licensing. The goal was to give banks that meet the capital requirements, the freedom to participate in any permissible, unregulated banking business and thus remove the compartmentalization. Over the past few years, the banking industry has seen some significant performance improvements as a result of government-led reforms over the years. Some of the reforms introduced that helped the banking sector in Ghana included; the legislation of the Foreign Exchange Bureau, the Non-Performing Assets Recovery Trust (NPART), the Financial Sector Adjustment Programme (FINSAP II and I), the promulgation of the new Banking Law in 1989, PNDC Law 225, and so on (Bawumia et al., 2008). With the passage of the new Banking Law and the other reforms introduced, the Bank of Ghana was sufficiently strengthened to perform its regulatory function. These reforms equally strengthened the banks and eventually lead to the improvement of their asset quality. The new minimum capital requirements introduced by the PNDC Law 225 enabled the banks to be adequately resourced to undertake high volume transactions and make sustained profits to be able to survive and grow organically. Non-Performing Assets Recovery Trust Act of 1990 was to cushion the Ghanaian banks against NPLs by offering them the opportunity to offload their NPLs to the Trust and focus on their core obligation of financial intermediation. According to Antwi-Asare and Addison (2000), the removal of the NPLs from the books of the banks helped improved their profitability and overall performance.

Following the promulgation of the new Banking Law in 1989, the number of banks doing business in Ghana increased to about 12. Since then the number of banks has grown exponentially and stood at 29 banks as at the close of 2015. It was envisaged that the number of banks operating in Ghana will hit 35 or more by the close of 2017. Owing to this development, many industry watchers have expressed a lot of scepticism about its ramifications on the Ghanaian economy. Although, the economy still has a very large unbanked population, hence a great potential for the growth of the banking industry; the size of the economy is still considered quite small to accommodate 35 or even more universal banks. When this happens, banks are likely to adopt unorthodox practices to grow their customer deposits and increase their profitability, which can erode assurance in the banking sector. The Bank of Ghana (BoG) adopted the International Financial Reporting Standards (IFRS) as a way of reducing systemic risk. The adoption of IFRS by institutions as issued by the International Accounting Standards Board (IASB) enable determine an application of a common set of financial reporting standards (Jermakowicz \& GornikTomaszewski, 2006; Neag, 2014). Furthermore, the establishment of a Collateral Registry and the Credit Reference Bureaus by the Bank of Ghana further seeks to encourage transparency, ease credit accessibility and the recapitalization of the banks, were all fashioned to address the risk and stabilize the banking system (Bawumia et al., 2008).

\subsection{Recapitalization}

Over the years, the BoG has issued some directives to all banks operating in the country to increase their minimum capital requirements to enable them to handle big-ticket transactions and for a stronger financial system to support the real sector of the economy. In 2003, BoG, for instance, issued a directive requiring all banks to increase stated capital to Ghe 7 million by the end of 2006. This was to enable the banks to hold the universal banking business license that allowed them to undertake commercial, merchant, and development banking without the need to acquire separate licenses. Again, on $14^{\text {th }}$ February 2008, a press release from the BoG set the minimum capital requirements for obtaining class 1 banking license (universal banking) at Ghф 60 million. This was to take effect at the end of 2009 by which time locally-owned banks would have a minimum of Ghø 25 million as stated capital. However, the local banks were supposed to meet this $\mathrm{GH} \phi 60$ million minimum capital requirement by December 2012 ( $\mathrm{PwC}$, 2008). Further to the above, new banks, both local and foreign, were required to have Ghф 
120 million to obtain a universal banking business license in Ghana according to the Central Bank. Existing banks do not have to meet this new minimum capital requirement nevertheless they can consistently assess their risk levels and augment their capital appropriately. The Gh 120 million minimum capital requirement has since been increased by BoG to Ghф 400 million for all banks, existing or new, effective December 31, 2018. The banking sector in Ghana has gone through a series of reforms and restructuring over the last fifteen years. Some of these reforms were occasioned by some happenings in the global economy. For instance, the 2008-09 global financial crisis, which was necessitated by the subprime mortgage crisis and the credit crunch in the USA and the Eurozone debt crises led to a significant dropped in foreign remittances and foreign direct investments (FDIs) into the country.

This adversely affected the flow of liquidity to the banks and even to the Ghanaian economy at large, which resulted in a drastic reduction of lending to the private sector and mounting non-performing loans (NPLs). The Central Bank responded by issuing a press release on $14^{\text {th }}$ February 2008 directing all universal banks to increase their minimum capital requirements to Ghe 60 million by December 2012. It was an attempt on the part of the regulator to cushion banks doing business in Ghana against liquidity risk and also to revamp confidence in the banking sector, which was seriously daunted by the growing NPLs and the ever-widening negative liquidity gap or mismatch in the industry. Before the second recapitalization directive, the Central Bank in August 2006 abolished the secondary reserve requirement. This announcement came as a big liquidity boost for the banks. The immediate impact was increased in lending to the private sector. The other noticeable changes that affected the operations of banks in Ghana within the last ten years included; the re-denomination of the cedi in July 2007 and the introduction of International Financial Reporting Standards (IFRSs) in the same year. The introduction of the ezwich payment system, which is aimed at reducing the number of cash transactions in the economy and improving accessibility to banking and retail services. The establishment of Credit Reference Bureaus to help track customers with multiple loans and advances across banks operating in Ghana. These bureaus amongst other objectives, aim at reducing the prevalence of non-performing loans (NPLs) in the Ghanaian banking industry.

\subsection{The Concept of Liquidity}

Liquidity is the bank's ability to maintain adequate funds to take care of its maturing obligations (Ibe, 2013). Any asset that is capable of being converted to cash easily without incurring any extra cost is a liquid asset. Therefore, if the conversion cannot be done at fair value or is done at a cost, then the asset is said to be not liquid. Gomez (2008) postulates that liquidity is the capacity of a bank to convert its assets into cash on demand. Gomez further asserted that cash is the most liquid of all assets, the only problem is that it loses value over time because of the time value of money. Olagunju, Adeyanju, and Olabode (2011) stated that liquidity is the assets in cash or which can quickly be converted into cash without any loss in value that would be available to settle short-term liabilities and/or maturing obligations. It is a generally held belief that cash is most liquid of all assets, therefore, liquidity is understood and calculated from the cashability of all other assets (Bhattacharya, 2008). The survival of any business organisation, banks inclusive, depends largely on its ability to generate adequate liquidity to support its day-to-day operations (Rob, 2010). Many a company collapsed not because they are not profitable, but they fail to raise enough liquidity to sustain their operations. Customers make withdrawal requests by issuing cheques and the bank has statutory obligation to honour the cheques and there is no question of postponing payment. Therefore, the bank has to maintain enough funds to take care of customers' withdrawal needs and cannot lock up funds in permanent securities (Gomez, 2008). Amid liquidity challenge banks still should make a profit for shareholders and to sustain their operations. According to Gomez (2008), a bank is supposed to direct its resources to profitable investments to make a profit for its shareholders. Making more profit will require locking up funds for the long term, which will have an adverse consequence on the bank's liquidity position. So, banks should strike a balance between profitability and liquidity by investing a portion of their funds in liquid assets and a portion in long-term assets. Cash, which is the most liquid asset, does not earn interest. Therefore, as banks will want to honour the withdrawal requests of customers without fail, keeping large amounts of cash will alienate the profit maximization objective of the bank.

\subsection{Elements of Liquidity}

Liquidity as already explained is the capacity to converted assets into cash on demand to settle maturing obligations. In other words, liquidity is the availability of cash and other current assets to cover accounts payable, short-term debts and other liabilities maturing within the accounting year. Liquidity management is effectively working capital management, which requires daily maintenance of liquidity to ensure that the company operates smoothly and be able to meet its obligations. A company is considered liquid if the current assets can adequately cover the current liabilities. Therefore, liquidity is a relative measure that looks at how the firm's cash and the other assets, which are readily convertible to cash without any loss, will be able to pay off the current liabilities or maturing obligations. The components of liquidity are mostly; Cash and cash equivalents, interest receivable, loans and advances (loan repayments) and so on. These components can vary significantly amongst banks depending on the type of ownership or attitude to risk. The foreign-owned banks will invest mostly in government securities. For instance, the United Bank for Africa (UBA)'s liquid funds to total assets show a significant increase in 2013. The bank applied a significant portion of its funds to purchase government securities in 2013 (PwC, 2014). The Bank of Baroda was equally cited in the PWC 2014 banking survey report for large investments in government securities against lending to the private sector. The loans and advances come next to government securities in the order of liquidity; they are the most profitable of the bank's assets (Shekhar \& Shekhar, 2005). Nevertheless, a high credit risk associated with loans and advances has made it unattractive for banks. Generally, the assets in the statement of financial position of banks are shown in descending order of liquidity. Cash and balances with the Central Bank are always at the top and the Property, Plant and Equipment (PPE), which is considered as not liquid of all the banks' assets is shown at the bottom. 


\subsection{Bank Financial Performance}

The Return on Asset (ROA) and Return on Equity (ROE) have been used extensively as measures of bank financial performance. ROA shows how effectively a bank is managing its assets, to generate income. It is the income earned on each unit of an asset usually expressed as a percentage. The challenge with ROA is that it excludes from the total assets off-balance sheet items thereby understating the value of assets. This situation can ultimately create a positive bias where ROA is overstated in the evaluation of bank performance. Nevertheless, Golin (2001); Rose and Hudgins (2008) have argued that ROA is one of the most important measures of profitability in recent banking literature. Studies such as Haron (2004), Hassan and Bashir (2003) and Naceur (2003) have all adopted ROA as a measure of profitability. Return on Equity (ROE) is considered as an alternative measure of profitability and it is computed by dividing net income by equity. It measures the income earned on each unit of shareholders' funds. The shortfall of this measure is that banks with high financial leverage tend to generate a higher ratio. Yet, banks with high financial leverage tend to have higher financial risk and therefore a higher possibility of bankruptcy.

\section{Methodology}

The research design demonstrates how the observed facts are collected, measured and analyzed. The study employed a quantitative research design. According to Cooper and Schindler (2001), quantitative research relates to numbers and measuring of observed facts; it involves reliance on observable hard facts for which data is collected, analyzed and described in terms of numbers. The data collected was in a panel form which is a longitudinal data set, since it captures the same financial and economic changes of different organizations over multiple periods. The combination of time series and cross-sectional observations, forming panel data gives more informative data, more degrees of freedom and more efficiency. The study employed criterion-based sampling in line with Palinkas et al. (2013) view, thus the availability of annual reports spanning 2006 to 2015. Based on the criterion-based sampling eighteen banks were selected mainly because of the availability of data and the fact that the banks were in existence during the period under consideration (2006-2015). The eighteen banks were; Standard Chartered Bank, SG-SSB, Ecobank, FBN Bank, Stanbic Bank, UBA, Zenith Bank, Bank of Africa, Agricultural Development Bank, Universal Merchant Bank, CAL Bank, First Atlantic Bank, UT Bank, Prudential Bank, Unibank Ghana, Fidelity Bank, Guaranty Trust Bank and Access Bank. Data were mainly collected from secondary sources which include; the annual financial reports of banks and Banking Supervision Department (BSD) reports submitted to the Bank of Ghana between the period of 2006 and 2015. Data were analysed using descriptive statistics and trend analysis.

\section{Results and Discussion}

\subsection{Descriptive Statistics}

Table 1 presents a summary of the descriptive statistics of the performance and liquidity variables employed in the study. These statistics were generated to give an overall description of the data used. The key descriptive measures were the mean, median, standard deviation, the minimum and maximum values over the period under consideration. It is observable that the current ratio and acid test ratio have the largest standard deviations which mean that they have significant variances compared to the other variables over the period. This is confirmed by the wide range between their minimum and maximum values. However, return on assets has the least standard deviation which suggests that it is the most stable and consistent variable compared to the other variables over the period. The average industry performance as measured by ROE stands at $14.59 \%$ with $-98 \%$ and $51 \%$ as a minimum and maximum values respectively whilst the average industry efficiency or asset utilization as measured by ROA also stand at $2.75 \%$ with $-10.53 \%$ and $8.92 \%$ as a minimum and maximum values respectively. A standard deviation of $2.99 \%$, which is the least amongst all the variables, is an indication of less variability in profits vis-à-vis the total assets of the banks operating in Ghana. This is very significant because the ROE and ROA show the earnings prowess of banks in Ghana. Thus, for every cedi of net owned funds (NOF), banks operating in Ghana generate an average return of Ghф 0.15, whilst the average return on a cedi of assets employed is Ghф 0.03. The average current ratio (CR) and the acid test ratio (ATR) which measure short-term solvency of banks operating in Ghana stood at 4.8:1 and 1.5:1 respectively.

According to Certified Management Accountant (CMA) Australia (2013) the ideal ratio is 2:1 or better which means banks operating in Ghana are performing relatively well when it comes to mobilizing short-term funds to honour their maturing obligations. However, an average loan deposit ratio (LDR) of about $67 \%$ shows that banks have committed an appreciable amount of their customer deposits into risk-assets (loans and advances). The minimum and maximum values of $9 \%$ and $174 \%$ respectively for LDR depict the varying attitude of banks towards committing customer deposits in risk-assets. This is evident, in high short-term solvency ratios such as CR, ATR and so on; meaning banks are far more interested in short-term, then long-term. This assertion is supported by the significantly high liquid funds total deposits ratio of about $75 \%$ which means, on average, up to $75 \%$ of customer deposits are either held as cash or invested in short-term investments such as government securities. Liquid funds total interest-bearing liabilities ratio of 1.2:1 is another manifestation of the well-resourced banking industry with adequate liquid funds to settle its maturing obligations. The industry's average return on capital (equity) is about $15 \%$, yet, the average 91 day Treasury bill rate is about $18 \%$ which suggests that either the cost of funds for the banks is probably high or the banks are operating with significantly high net overhead costs. The high cost of funds could have been occasioned by the banks' deposit mix, thus having more 'term deposits' which is relatively expensive, in their mix as compare to 'demand deposits' will naturally lead the higher cost of funds. Therefore, dwindling the net interest margin and subsequently the pre-tax profit. This amongst other things might have been responsible for the unimpressive showing of both ROE and the ROA as seen from the descriptive statistics. These ratios have collectively shown that there was no liquidity risk in the Ghanaian banking industry over the study periods. 


\begin{tabular}{c|c|c|c|c|c|c}
\multicolumn{7}{c}{ Table-1. Descriptive statistics of variables. } \\
\hline Variables & Observations & Mean & Median & Std. Dev. & Minimum & Maximum \\
\hline ROE & 180 & 0.145972 & 0.164288 & 0.195654 & -0.982837 & 0.51381 \\
\hline ROA & 180 & 0.027508 & 0.028045 & 0.029865 & -0.105313 & 0.089217 \\
\hline CR & 180 & 4.87184 & 3.144594 & 5.149784 & 0.328672 & 32.13421 \\
\hline ATR & 180 & 1.544268 & 1.212424 & 1.823605 & 0.28195 & 21.98302 \\
\hline LTD & 180 & 0.753295 & 0.708112 & 0.295641 & 0.292972 & 2.161055 \\
\hline LIB & 180 & 1.206985 & 1.072594 & 0.668593 & 0.282228 & 4.124094 \\
\hline LDR & 180 & 0.6703 & 0.634283 & 0.253441 & 0.090929 & 1.741183 \\
\hline
\end{tabular}

Note: ROE - Return on equity; ROA - Return on asset; CR - Current ratio; ATR - Acid test ratio;

LTD - Liquid funds total deposit ratio; LIB - Liquid funds total interest-bearing liabilities; LDR - Loan deposit ratio

\subsection{Liquidity Trend of Banks}

As shown graphically in Figure 1, the year 2011 recorded the highest liquidity for banks in Ghana. Nevertheless, banks recorded one of their lowest performances in terms of ROE in the same year, apart from 2006, 2009 and 2015. Again, in 2014, the banks recorded the least average liquidity position. Yet, their highest ROE and ROA performances were also recorded in that same year. A look at 2015 performance graphs in Figures 2 and 3 showed an obvious declined in bank performance in terms of equity and assets utilization. But the average liquidity graph in Figure 1 depicted an increment in liquidity position for 2015 as compared to the previous year. This seemingly inverse relationship between the two opposing graphs should not be misconstrued as an inverse relationship between bank performance and liquidity because it could simply mean that, the banks were more efficient and prudent in managing relatively less liquidity to generate higher returns. Bank profitability is determined by so many factors including but not limited the following; efficient management, technology, favourable government policies and central bank directives and so on. The trend clearly showed that the banks were liquid throughout the study period except that they were less liquid at certain periods, particularly, in 2013 and 2014 which recorded average liquidity of 1.54 and 1.41 respectively. For instance, liquidity of 2.183 in 2011 , indicates that Ghe 2.183 of current assets are available to cover Ghe 1 of current liabilities. Again, liquidity (1.409) in 2011, indicates that Ghe 1.409 of current assets are available to cover Ghe 1 of current liabilities. It is worth noting that the average liquidity figures were all above 1, meaning the banks had sufficient funds to settle their maturing obligations. Simply, the banks did not face any liquidity risk during the periods under consideration.

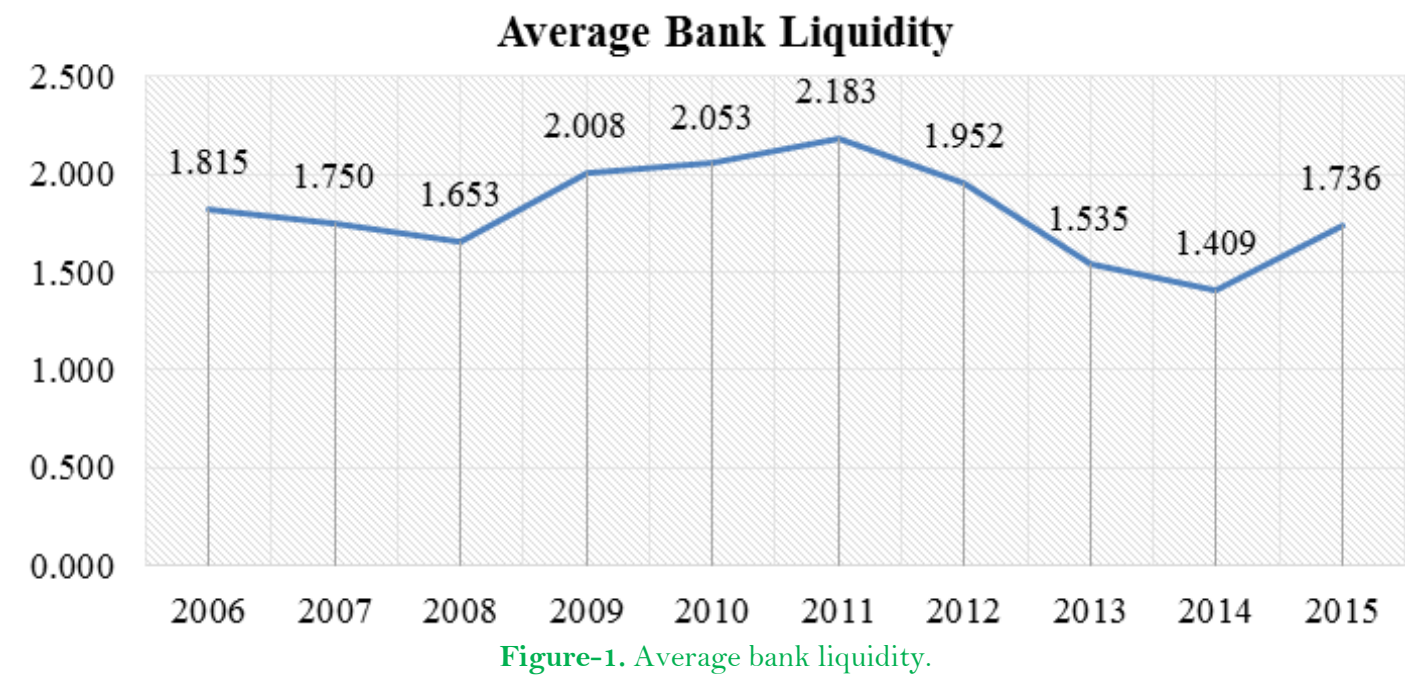

\subsection{Financial Performance Trend of Banks}

From the graphical presentation in Figures 2 and 3; banks performance during the study period was quite erratic, thus moving up and down haphazardly. The year 2006 recorded the lowest performance for banks in Ghana, representing $6.74 \%$ and $0.83 \%$ for ROE and ROA respectively whilst 2014 was the highest point, registering a return on equity of $24.23 \%$ and a return on assets of $4.57 \%$. Interestingly, ROE dropped significantly in 2015 to $9.9 \%$ from $24.23 \%$ in the preceding year. This was mainly due to recapitalization by four banks, namely; First Atlantic Bank, SG-SSB, uniBank Ghana and Universal Merchant Bank. The dropped in ROA also was not that significant to suggest the reduction was occasioned by low profitability in 2015. However, the steady performance of the banks came between 2011 and 2014 when they recorded consistent growth in both equity and asset utilization. Apart from 2006, 2009, 2011 and 2015 which recorded dips for ROE and 2006, 2009, and 2015 for ROA, the rest of the years during the study period all trended upwards. The dipped in performance for these years was because of some significant losses recorded by Agricultural Development Bank, Bank of Africa, Universal Merchant Bank and the UT Bank. 


\section{Average Return on Equity}
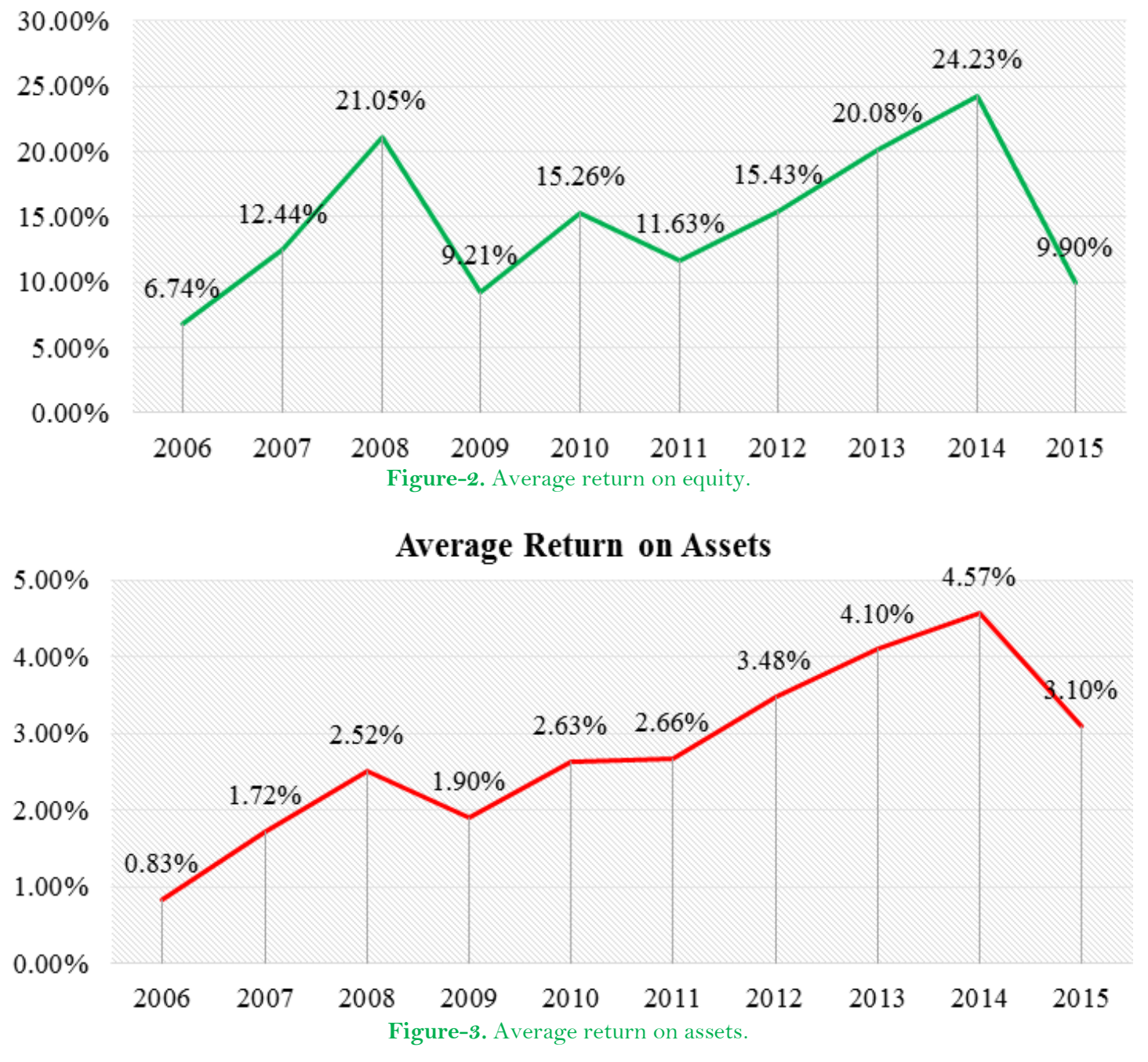

\section{Conclusion and Recommendations}

Banks, just like all other forms of businesses are faced with numerous risks such as interest rate risk, exchange rate risk, liquidity risk, operating risk, political risk, technological risk and default risk (credit risk). The trend analysis shows that the liquidity of banks is to some extent link to the bank financial performance. This means the amount of liquidity held by a bank in Ghana will necessarily influence its financial performance. This is consistent with the overall conclusion of Malik, Awais, and Khursheed (2016) that liquidity ratios affect profitability ratios. Liquidity risk may have diverse effects on a bank's earnings and capital base depending on how it is managed. Lack of liquidity or improper management of it can collapse an otherwise profitable business organisation. The analysis further highlights the importance of liquidity to banks in terms of profitability and survival. Taking the various determinants of bank liquidity into consideration, and how liquidity impacts bank profitability, efficient management of it would not only inure to the benefit of banks but also to individuals and business entities and thus the whole economy. It is further recommended that bank capitalization ought to be encouraged with the goal that bank financial performance can be improved. Banks should endeavour to retain earnings in other to boost capital as opposed to paying exorbitant bonuses. The well-capitalized banking industry will guarantee financial stability and make the sector more robust against external shocks. Efficient liquidity management should be adopted by bank managers to ensure that banks operate profitably and do not become insolvent. Since it has been established empirically that high levels of liquidity will guarantee better financial performance.

\section{References}

Amer, D. W. (2007). Financial stability, economic growth, and the role of law. Cambridge: Cambridge University Press.

Antwi-Asare, T. O., \& Addison, E. K. Y. (2000). Financial sector reforms and bank performance in Ghana. London, United Kingdom: Overseas Development Institute.

Bawumia, M., Owusu-Danso, T., \& McIntyre, A. (2008). IMF survey magazine: Countries \& regions, Ghana's reforms transform its financial sector. Retrieved from: http://www.imf.org/external/pubs/ft/.

Bhattacharya, H. (2008). Working capital management (2nd ed.). New Delhi, India: PHI Learning Private Ltd.

Board of Governors of the Federal Reserve System. (2014). What is the difference between a bank's liquidity and its capital? Retrieved from: http://www.federalreserve.gov/faqs/cat 21427.htm.

Certified Management Accountant (CMA) Australia. (2013). Ratio analysis techniques. Retrieved from: https://www.cmaweblive.org/.

Cooper, D. R., \& Schindler, P. S. (2001). Business research methods. Boston Irwin: McGraw-Hill.

Golin, J. (2001). The bank credit analysis handbook: A guide for analysts, bankers and investors. Boston: John Wiley \& Sons (Asia) Pre Ltd.

Gomez, C. (2008). Financial markets, institutions and services. New Delhi, India: Prentice-Hall.

Haron, S. (2004). Determinants of Islamic bank profitability. The Global Journal of Finance and Economics, 1(1), 11-33.

Hassan, K., \& Bashir, M. (2003). Determinants of Islamic banking profitability. Retrieved from: http://www.finance.nsysu.edu.tw/SFM.

Ibe, S. O. (2013). The impact of liquidity management on the profitability of banks in Nigeria. Journal of Finance and Bank Management, I(1), $37-48$.

Jermakowicz, E. K., \& Gornik-Tomaszewski, S. (2006). Implementing IFRS from the perspective of EU publicly traded companies. Journal of International Accounting, Auditing and Taxation, 15(2), 170-196.Available at: https://doi.org/10.1016/j.intaccaudtax.2006.08.003.

Lartey, V., Antwi, S., \& Boadi, E. K. (2013). The relationship between liquidity and profitability of listed banks in Ghana. Retrieved from: http://www.ijbssnet.com/journals/. [Accessed September 12, 2015].

Leonard, M. (2011). Liquidity risk measurement and management - Basel III and beyond. Boston: Xlibris Corporation. 
Malik, M. S., Awais, M., \& Khursheed, A. (2016). Impact of liquidity on profitability: A comprehensive case of Pakistan's private banking sector. International Journal of Economics and Finance, 8(3), 69.Available at: https://doi.org/10.5539/ijef.v8n3p69.

Moulton, H. G. (1918). Commercial banking and capital formation. The Journal of Political Economy, 26(7), 32-38.

Naceur, S. B. (2003). The determinants of the Tunisian banking industry profitability: Panel evidence. Retrieved from: http://www.mafhoum.com/press6/174E11.pdf.

Neag, R. (2014). The effects of IFRS on net income and equity: Evidence from Romanian listed companies. Procedia Economics and Finance, 15, 1787-1790.Available at: https://doi.org/10.1016/s2212-5671(14)00860-0.

Olagunju, A., Adeyanju, O. D., \& Olabode, O. S. (2011). Liquidity management and commercial banks' profitability in Nigeria. Research Journal of Finance and Accounting, 2(7/8), 24-39.

Palinkas, L. A., Horwitz, S. M., Green, C. A., Wisdom, J. P., Duan, N., \& Hoagwood, K. (2013). Purposeful sampling for qualitative data collection and analysis in mixed method implementation research. New York: Springer.

PwC. (2008). 2008 Ghana banking survey. Accra, Ghana: PwC.

PwC. (2014). 2014 Ghana banking survey. Accra, Ghana: PwC.

Rob, W. (2010). Loan sharp. Herts, United Kingdom: Academy Press Ltd.

Rose, P. S., \& Hudgins, S. C. (2008). Bank management ङ financial series (7th ed.). New York: McGraw Hill/Irwin.

Shekhar, K. C., \& Shekhar, L. (2005). Banking theory and practice (19th ed.). New Delhi, India: Kay Kay Printers.

Tan, C. H. (2005). Financial markets and institutions in Singapore. Singapore: Singapore University Press. 